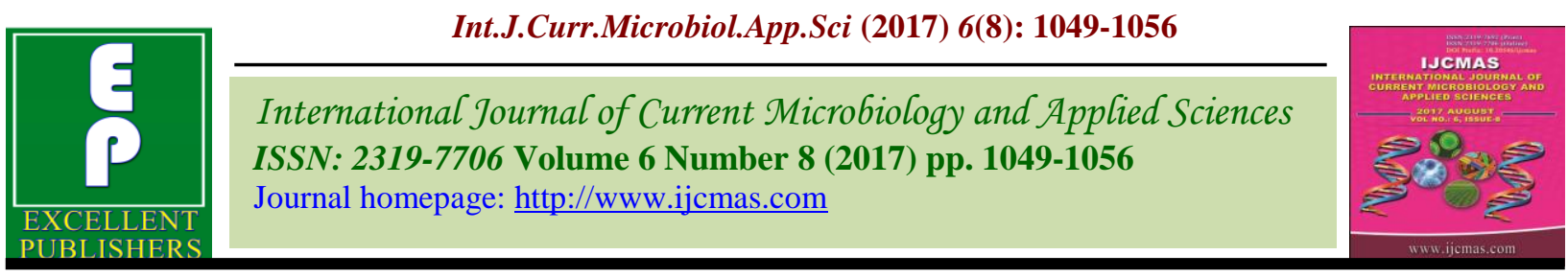

Original Research Article

https://doi.org/10.20546/ijcmas.2017.608.130

\title{
Effect of NPK on Plant Growth, Flower Quality and Yield of Gerbera (Gerbera jamesonii L.) cv. Ruby Red under Naturally Ventilated Polyhouse Condition
}

\author{
Tovika J. Ayemi*, Devi Singh and Urfi Fatmi \\ Department of Horticulture (Floriculture and Landscaping) [NAI], Sam Higginbottom University \\ of Agriculture Technology and Sciences, Allahabad, 211007 (U.P) India \\ *Corresponding author
}

\begin{tabular}{|c|c|}
\hline & B S \\
\hline & \multirow{5}{*}{ 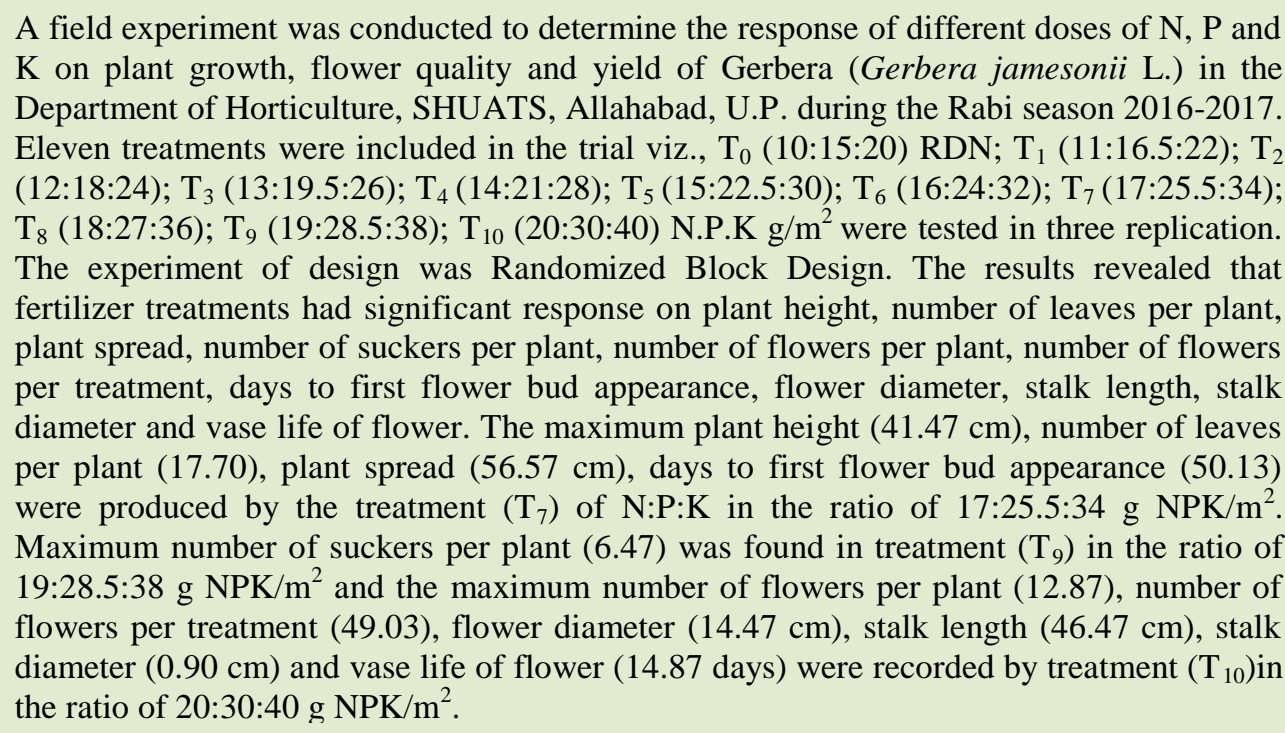 } \\
\hline $\begin{array}{l}\text { Flower quality } \\
\text { and yield. }\end{array}$ & \\
\hline Article Info & \\
\hline $\begin{array}{l}\text { Accepted: } \\
\text { 14 June } 2017 \\
\text { Available Online: } \\
10 \text { August } 2017\end{array}$ & \\
\hline & \\
\hline
\end{tabular}

\section{Introduction}

Gerbera (Gerbera jamesonii L.) commonly known as Transval daisy, 'Barbeton daisy' or African daisy belonging to family Asteraceae is an important flower grown throughout the world. It bears flowers of various colours and suits very well for floral arrangement. Due to the increasing demand of this cut flower which generally grows under protected structures there arises a need for better adoption of various cultural factors to produce flowers of export quality. Gerbera is very popular and widely used as a decorative garden plant or as a cut flower. Gerbera can be used in landscapes as bedding plants for borders and flower beds or as a cut flower for table arrangement. The domesticated cultivars are mostly a result of a cross between Gerbera jamesonii and another South African species Gerbera viridifolia. The cross is known as Gerbera hybrida. Thousands of 
cultivars exist they vary greatly in shape and size. Colours include white, yellow, orange, red and pink. The centre of the flower is sometimes black. Often the same flower can have petals of several different colours. Gerbera is also important commercially. It is the fifth most used cut flower in the world (after rose, carnation, chrysanthemum and tulip). It is also used as a model organism in studying flower formation. Gerbera contains naturally occurring coumarin derivatives. Gerbera is a tender perennial plant. It is attractive to bees, butterflies and birds.

Next to water, nutrients are the important input for guiding sustainable growth of crops. Thus, fertilizers are the kingpin in the present system of horticulture. The healthy growth of plants requires all fertilizer elements; a lack of one can result in many symptoms. While all elements play a role in plant development and, subsequently, flower development, phosphorus is the element most responsible for stimulating stronger bud and flower development. This is because phosphorus is a vital nutrient involved in stimulating and enhancing bud development and set, seed formation and blooming. It can help quicken plant maturity as well. It's also vital in photosynthesis and respiration. Root stimulating fertilizers are also often higher in phosphorus than the other two primary nutrients because phosphorus helps strengthen young roots and gives them a strong start. Nitrogen and potassium also helps in plant growth. Nitrogen stimulates stronger green growth, which provides healthy stems and leaves while potassium is vital to several areas of plant growth, including drought tolerance, disease resistance, stem strength, improved texture, colour and photosynthesis.

\section{Materials and Methods}

The present investigation was conducted to study the effect of NPK on plant growth, flower quality and yield of gerbera at the
Research Farm of Department of Horticulture, SHUATS during Rabi season November 2016- March 2017. The soil of experimental site was sandy loam in texture with $\mathrm{pH}$ of 7.3, E.C of $0.18 \mathrm{dSm}^{-1}$ and organic carbon of $0.40 \%$. The available nitrogen, phosphorus and potassium contents were 205.2, 22.5 and $280 \mathrm{~kg} \mathrm{ha}^{-1}$ respectively. The experiment was laid out in randomized block design with three replications comprised of 11 treatment combinations viz., $\mathrm{T}_{0}(10: 15: 20) \mathrm{RDN} ; \mathrm{T}_{1}$ (11:16.5:22); $\mathrm{T}_{2}$ (12:18:24); $\mathrm{T}_{3}(13: 19.5: 26)$; $\mathrm{T}_{4}(14: 21: 28) ; \mathrm{T}_{5}(15: 22.5: 30) ; \mathrm{T}_{6}(16: 24: 32)$; $\mathrm{T}_{7} \quad(17: 25.5: 34) ; \quad \mathrm{T}_{8} \quad(18: 27: 36) ; \quad \mathrm{T}_{9}$ $(19: 28.5: 38) ; \mathrm{T}_{10}(20: 30: 40)$ N.P.K g/m² . The seedlings of cv Ruby Red was transplanted at spacing of $30 \mathrm{~cm} \times 30 \mathrm{~cm}$. Different growth parameters like plant height, number of leaves plant $^{-1}$, plant spread, number of suckers plant ${ }^{1}$, quality parameters like days to first flower bud appearance, flower diameter, stalk length, stalk diameter, vase life of flower and yield parameters like number of flowers plant ${ }^{-1}$ and number of flowers treatment ${ }^{-1}$ were taken.

\section{Results and Discussion}

The results of the experiment have been reported and discussed in foregoing chapters. The same are discussed here under.

\section{(A) Growth}

All growth parameters were significantly influenced by different treatments. The data presented in table 1 shows that maximum plant height $(41.47 \mathrm{~cm})$ was found to be in treatment $\mathrm{T}_{7}\left(17: 25.5: 34 \mathrm{~g} \mathrm{NPK} / \mathrm{m}^{2}\right)$ followed by $\mathrm{T}_{6}\left(16: 24: 32 \mathrm{~g} \mathrm{NPK} / \mathrm{m}^{2}, 40.17 \mathrm{~cm}\right)$ which were found to be at par while the minimum plant height $(25.45 \mathrm{~cm})$ was recorded in treatment $\left(\mathrm{T}_{0}\right)$ control. Significantly maximum plant height may be due to increase in fertilization of macro nutrients from the required level. Although, all the fertilizers used have their importance, higher dose of potassium among the macro nutrients was 
found to be the most crucial for increase in plant height because potassium enhances the synthesis and translocation of carbohydrate. As the potassium dissolves in the soil water is taken up by the plant roots and the exchangeable $\mathrm{K}$ is released into the soil solution to maintain equilibrium between the two forms. Potassium has also been reported to be involved in the synthesis of peptide bond, and protein and carbohydrate metabolism, and also participates in rapid cell division and differentiation (Belorkar et al., 1992). Nitrogen is a constituent of protein and nucleic acid, which is helpful in plant growth (Haque, 2001) and also promotes rapid growth. Phosphorus also encourages cell walls and length of the plant resulting in higher plant height in gerbera. Similar result was reported by Amin et al., (2011). In contrary to my findings, Acharya et al., (2004) also reported highest plant height with the application of nitrogen and phosphorus in marigold.

The maximum numbers of leaves (17.70) were recorded in treatment $\mathrm{T}_{7}(17: 25.5: 34 \mathrm{~g}$ $\left.\mathrm{NPK} / \mathrm{m}^{2}\right)$ followed by $\mathrm{T}_{6} \quad(16: 24: 32 \mathrm{~g}$ $\mathrm{NPK} / \mathrm{m}^{2}, 16.43 \mathrm{~cm}$ ) while minimum numbers of leaves (8.73) were found to be in treatment $\left(\mathrm{T}_{0}\right)$ control. Significantly maximum number of leaves per plant may be due to increase in fertilization of macro nutrients from the required level. Higher dose of potassium among the macro nutrients resulted in maximum number of leaves which might be due to the synthesis of peptide bond, protein and carbohydrate metabolism. Potassium regulates the opening and closing of stomata in photosynthesis and therefore regulates carbon dioxide uptake. Nitrogen is associated with high photosynthetic activity and vigorous vegetative growth which has the tendency to increase leaf cell number and cell size with an overall increase in leaf production. Phosphorous also plays a role in photosynthesis, respiration, energy storage and transfer resulting in maximum number of leaves in gerbera. Similar result was reported by Amin et al., (2011).

The maximum plant spread $(56.57 \mathrm{~cm})$ was recorded in treatment $\mathrm{T}_{7}(17: 25.5: 34 \mathrm{~g}$ $\left.\mathrm{NPK} / \mathrm{m}^{2}\right)$ followed by $\mathrm{T}_{6} \quad(16: 24: 32 \mathrm{~g}$ $\mathrm{NPK} / \mathrm{m}^{2}, 55.67 \mathrm{~cm}$ ) which was found to be at par while minimum plant spread $(30.50 \mathrm{~cm})$ was recorded to be in treatment $\left(\mathrm{T}_{0}\right)$ control. Significantly maximum plant spread may be due to application of chemical fertilizer which provided sufficient nutrition to support development process. Although, all the fertilizers used have their importance, higher dose of potassium among the macro nutrients was found to be the most crucial for increase in plant spread. Potassium enhances the synthesis and translocation of carbohydrate. It triggers activation of enzymes and is essential for production of Adenosine Triphosphate (ATP) which is an important source for many chemical processes during plant growth. Nitrogen also promotes rapid vegetative growth and synthesizes amino acids which in turn form protein. Phosphorus also stimulates early growth and encourages cell wall and length of plant resulting in maximum plant spread in gerbera. Similar result was reported by Barad et al., (2010).

The maximum numbers of suckers (6.47) were recorded to be in treatment $T_{9}$ (19:28.5:38 g NPK $/ \mathrm{m}^{2}$ ) followed by (5.87) with treatment $\mathrm{T}_{8}\left(18: 27: 36 \mathrm{~g} \mathrm{NPK} / \mathrm{m}^{2}\right)$ which was found to be at par while minimum number of suckers (3.33) was recorded in $\mathrm{T}_{0}$ (10:15:20 g NPK $/ \mathrm{m}^{2}$ ). Significantly maximum number of suckers per plant may be due to increase in levels of nitrogen, phosphorus and potassium were found to promote development of suckers and improve flowering in gerbera. The potassium in soil available to plant is dissolved in the soil water. This is taken up by the plant roots and result in development of maximum suckers in 
gerbera. Nitrogen is a basic ingredient of vital compounds-nucleic acid and enzymes and helps in vegetative growth. Similar result was obtained by Dalal et al., (2005).

\section{(B) Quality parameters}

The data presented in table 1 shows that minimum number of days (50.13) taken for flower bud appearance was recorded in treatment $\mathrm{T}_{10}\left(20: 30: 40 \mathrm{~g} \mathrm{NPK} / \mathrm{m}^{2}\right)$ followed by (51.43) with treatment $\mathrm{T}_{9}(19: 28.5: 38 \mathrm{~g}$ $\left.\mathrm{NPK} / \mathrm{m}^{2}\right)$ whereas treatment $\left(\mathrm{T}_{0}\right)$ took maximum number of days (57.13) for first flower bud appearance. Significantly minimum number of days taken to first flower bud may be due to increase in fertilization of macro nutrients from the required level. Increased in higher potassium dose among the macro nutrients resulted in minimum days taken to flower bud appearance due to the improve efficiency of photosynthesis, increased resistant to some diseases and greater water use efficiency. It helps to maintain a normal balance between carbohydrates and proteins resulting in minimum days taken to flower bud appearance. Similar result was reported by Nayak et al., (2005).

Maximum flower diameter $(14.47 \mathrm{~cm})$ was recorded in treatment $\mathrm{T}_{10} \quad(20: 30: 40 \mathrm{~g}$ $\mathrm{NPK} / \mathrm{m}^{2}$ ) followed by treatment $\mathrm{T}_{9}$ $\left(19: 28.5: 38 \mathrm{~g} \mathrm{NPK} / \mathrm{m}^{2}, 13.87 \mathrm{~cm}\right)$ which was found to be at par while minimum flower diameter $(9.67 \mathrm{~cm})$ was recorded to be in treatment $\left(\mathrm{T}_{0}\right) \quad$ control. Significantly maximum flower diameter might be due to the presence of higher potassium dose among the macro nutrients which is also a major osmotically active component in plant cells contributing to cell turgor and enhancing the capacity of plant cell to retain water and nutrients. Potassium also results in superior quality of flower diameter due to the improved efficiency of photosynthesis. Nitrogen and phosphorus also resulted in maximum increase in nutrient uptake and stimulates blooming resulting in maximum flower diameter in gerbera. Similar result was reported by Mohariya et al., (2004).

Maximum stalk length $(46.47 \mathrm{~cm})$ was recorded to be in treatment $\mathrm{T}_{10}(20: 30: 40 \mathrm{~g}$ $\left.\mathrm{NPK} / \mathrm{m}^{2}\right)$ followed by $\mathrm{T}_{9} \quad(19: 28.5: 38 \mathrm{~g}$ $\left.\mathrm{NPK} / \mathrm{m}^{2}, 44.80 \mathrm{~cm}\right)$ and $\mathrm{T}_{3}(13: 19.5: 26 \mathrm{~g}$ $\mathrm{NPK} / \mathrm{m}^{2}, 44.79 \mathrm{~cm}$ ) which were found to be at par while minimum stalk length $(26.91 \mathrm{~cm})$ was recorded in treatment $\left(\mathrm{T}_{0}\right)$ control.

Significantly maximum stalk length may be due to increase in fertilization of macro nutrients from the required level. The highest level of potassium dose among the macro nutrients has pronounced effect on stalk length in gerbera. Plants take up potassium in ionic form as $\mathrm{K}^{+}$. Potassium triggers activation of enzymes and is essential for production of (ATP) Adenosine Triphosphate which is an important energy source for many chemical causes and this result in maximum stalk length in gerbera. Nitrogen is also a constituent of nucleic acid and promotes rapid growth. Phosphorus also encourages cell walls and stalk length. Similar result was recorded by Amin et al., (2011).

Maximum stalk diameter $(0.90 \mathrm{~cm})$ was recorded to be in treatment $\mathrm{T}_{10}(20: 30: 40 \mathrm{~g}$ $\mathrm{NPK} / \mathrm{m}^{2}$ ) followed by treatment $\mathrm{T}_{9}$ $\left(19: 28.5: 38 \mathrm{~g} \mathrm{NPK} / \mathrm{m}^{2}, 0.88 \mathrm{~cm}\right)$ which was found to be at par while minimum stalk diameter $(0.62 \mathrm{~cm})$ was recorded in treatment $\left(\mathrm{T}_{0}\right)$ control. Significantly maximum stalk diameter $(\mathrm{cm})$ may be due to increase in fertilization of macro nutrient from the required level. Chemical fertilizer provides sufficient nutrition to support development process during plant growth. 
Table.1 Effect of NPK on growth and quality of gerbera

\begin{tabular}{|c|c|c|c|c|c|c|c|c|c|}
\hline $\begin{array}{l}\text { Treatment } \\
\left(\mathrm{g} N \mathrm{NP} / \mathrm{m}^{2}\right)\end{array}$ & $\begin{array}{l}\text { Plant } \\
\text { height } \\
(\mathrm{cm})\end{array}$ & $\begin{array}{l}\text { No. of } \\
\text { leaves/ } \\
\text { plant }\end{array}$ & $\begin{array}{l}\text { Plant } \\
\text { spread } \\
(\mathrm{cm})\end{array}$ & $\begin{array}{l}\text { No. of } \\
\text { suckers/ } \\
\text { plant }\end{array}$ & $\begin{array}{l}\text { Days to first } \\
\text { bud } \\
\text { appearance }\end{array}$ & $\begin{array}{l}\text { Flower } \\
\text { diameter } \\
\text { (cm) }\end{array}$ & $\begin{array}{l}\text { Stalk } \\
\text { length } \\
(\mathrm{cm})\end{array}$ & $\begin{array}{l}\text { Stalk } \\
\text { diameter } \\
(\mathrm{cm})\end{array}$ & $\begin{array}{l}\text { Vase life } \\
\text { of flower } \\
\text { (days) }\end{array}$ \\
\hline $10: 15: 20$ & 25.45 & 8.73 & 30.50 & 3.33 & 57.13 & 9.67 & 26.91 & 0.62 & 6.63 \\
\hline $11: 16.5: 22$ & 34.13 & 15.20 & 54.67 & 5.23 & 56.33 & 11.43 & 40.39 & 0.79 & 12.67 \\
\hline $12: 18: 24$ & 29.37 & 12.33 & 51.28 & 4.53 & 54.87 & 12.29 & 38.18 & 0.79 & 7.07 \\
\hline $13: 19.5: 26$ & 28.59 & 11.93 & 50.60 & 4.53 & 55.03 & 11.67 & 44.80 & 0.74 & 7.67 \\
\hline $14: 21: 28$ & 30.52 & 10.37 & 47.43 & 4.67 & 55.27 & 11.74 & 35.27 & 0.68 & 10.77 \\
\hline $15: 22.5: 30$ & 31.67 & 14.33 & 46.64 & 4.60 & 54.47 & 11.78 & 34.66 & 0.79 & 8.40 \\
\hline $16: 24: 32$ & 40.17 & 16.43 & 55.67 & 4.60 & 51.43 & 11.56 & 36.05 & 0.78 & 7.53 \\
\hline $17: 25.5: 34$ & 41.47 & 17.70 & 51.28 & 3.50 & 50.13 & 11.08 & 40.85 & 0.74 & 8.43 \\
\hline $18: 27: 36$ & 35.66 & 11.80 & 56.57 & 5.87 & 52.47 & 12.64 & 42.39 & 0.83 & 7.53 \\
\hline $19: 28.5: 38$ & 38.75 & 11.33 & 47.57 & 6.47 & 52.27 & 13.87 & 44.80 & 0.88 & 13.83 \\
\hline $20: 30: 40$ & 32.41 & 12 & 51.74 & 3.60 & 55.27 & 14.47 & 46.47 & 0.90 & 14.87 \\
\hline Mean & 33.90 & 12.92 & 49.08 & 4.63 & 54.06 & 12.02 & 38.79 & 0.78 & 9.58 \\
\hline F-test & $\mathbf{S}$ & $\mathbf{S}$ & $\mathbf{S}$ & $\mathbf{S}$ & $\mathbf{S}$ & $\mathbf{S}$ & $\mathbf{S}$ & $\mathbf{S}$ & $\mathbf{S}$ \\
\hline S.Ed. ( \pm$)$ & 1.04 & 0.51 & 0.69 & 0.30 & 0.94 & 0.72 & 1.63 & 0.03 & 0.35 \\
\hline C.D at $5 \%$ & 2.17 & 1.07 & 1.44 & 0.62 & 1.96 & 1.51 & 3.40 & 0.06 & 0.74 \\
\hline
\end{tabular}


Table.2 Effect of NPK on yield of gerbera

\begin{tabular}{|l|l|l|}
\hline Treatment $\left.\mathbf{( g ~ N P K} / \mathbf{m}^{\mathbf{2}}\right)$ & No. of flowers/plant & No. of flowers per treatment \\
\hline $10: 15: 20$ & 7.13 & 65.27 \\
\hline $11: 16.5: 22$ & 10.87 & 97.80 \\
\hline $12: 18: 24$ & 9.27 & 83.83 \\
\hline $13: 19.5: 26$ & 8.27 & 74.83 \\
\hline $14: 21: 28$ & 8.40 & 75.30 \\
\hline $15: 22.5: 30$ & 9.67 & 87.87 \\
\hline $16: 24: 32$ & 8.33 & 74.77 \\
\hline $17: 25.5: 34$ & 8.87 & 79.40 \\
\hline $18: 27: 36$ & 10.93 & 98.43 \\
\hline $19: 28.5: 38$ & 11.73 & 105.73 \\
\hline $20: 30: 40$ & 12.87 & 115.90 \\
\hline Mean & 9.67 & 87.19 \\
\hline F-test & $\mathbf{S}$ & $\mathbf{S}$ \\
\hline S.Ed. $(\mathbf{\pm})$ & 0.59 & 0.42 \\
\hline C.D at 5\% & 1.22 & 0.87 \\
\hline
\end{tabular}

Fig.1 Number of flowers of Gerbera (Gerbera jamesonii L.) per treatment as influenced by different NPK doses at different intervals

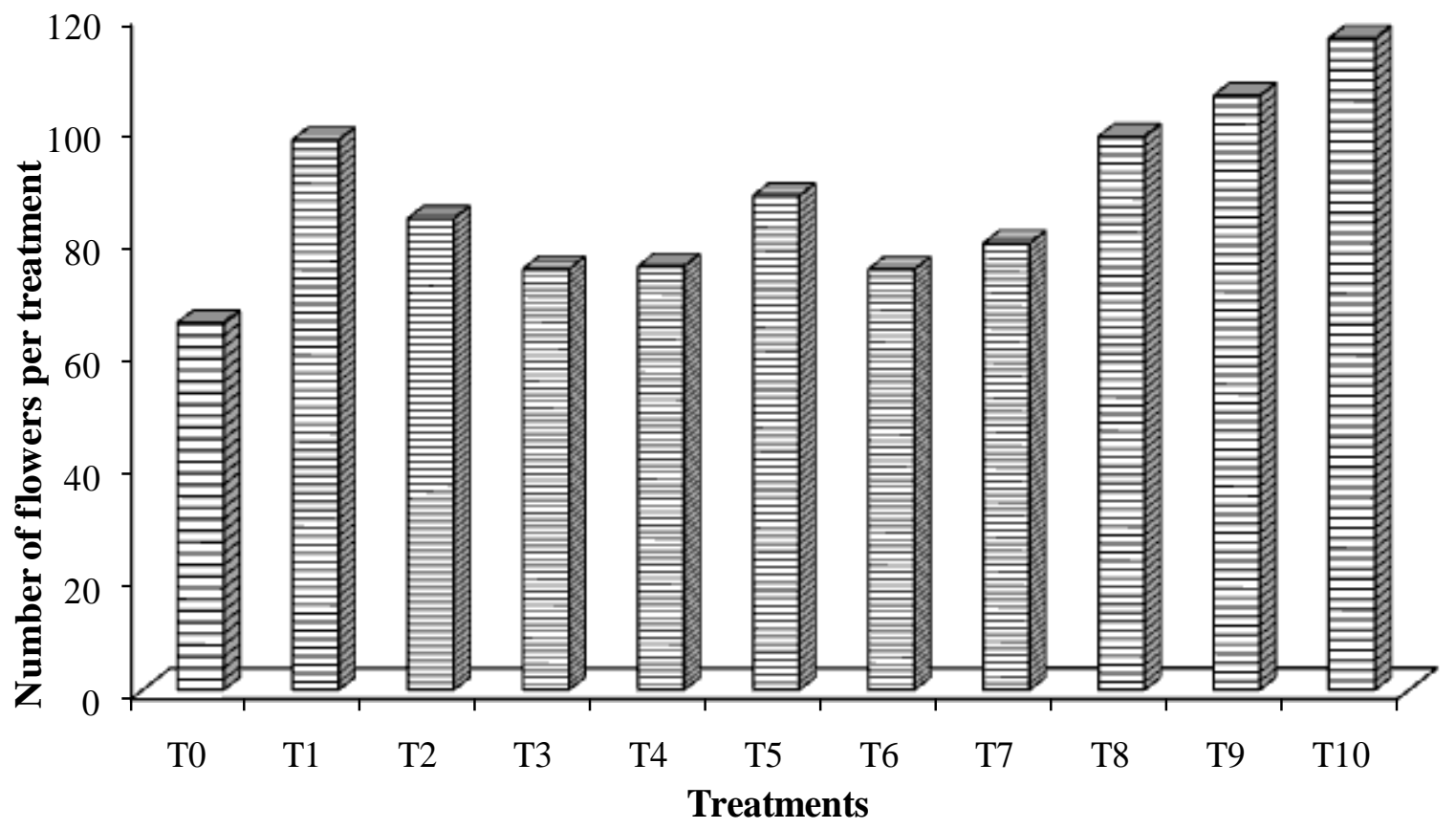


Higher dose of potassium level among the macro nutrient resulted in maximum stalk diameter as it strengthens cell walls and acts as a catalyst in iron uptake. Nitrogen is needed for vegetative growth and is a part of proteins, enzymes and vitamins. Phosphorus also gets plants off to a good start and forms a good root filter system in the soil to efficiently pick up the other available nutrients and water. It improves the strength and stamina of the plant resulting in maximum stalk diameter in gerbera. Similar result was recorded by Dalal et al., (2005).

The maximum number of days (14.87) taken for vase life was recorded in treatment $T_{10}$ (20:30:40 g NPK $\left./ \mathrm{m}^{2}\right)$ followed by (13.83 days) with treatment $\mathrm{T}_{9}$ (19:28.5:38 NPK $\mathrm{g} / \mathrm{m}^{2}$ ) while minimum number of days taken for vase life of flower was recorded to be minimum (6.63) in treatment $\left(\mathrm{T}_{0}\right)$ control. Significantly maximum number of days for vase life may be due to increase in fertilization of macro nutrients from the required level. Similar results were obtained by Amin et al., (2011).

\section{(C) Yield parameters}

The data presented in table 2 shows that maximum numbers of flower per plant (12.87) were recorded in treatment $T_{10}$ (20:30:40 g NPK $/ \mathrm{m}^{2}$ ) followed by treatment $\mathrm{T}_{9}\left(19: 28.5: 38 \mathrm{~g} \mathrm{NPK} / \mathrm{m}^{2}, 11.73\right)$ which was found to be at par while minimum number of flowers (7.13) was recorded in treatment $\left(\mathrm{T}_{0}\right)$ control. Significantly maximum number of flowers per plant may be due to the highest level of potassium which had pronounced effect on number of flowers among the macro nutrients. Balanced dose of nitrogen, phosphorus and potassium seemed to have increased the vegetative growth favorable for the synthesis of peptide bond, protein and carbohydrate metabolism that are essential for flower development. High potassium with appropriate dose of nitrogen and phosphorus seemed to have increased the number of flowers per plant in gerbera. Similar result was obtained by Nayak et al., (2005).

Maximum yield of flower per treatment (115.90) was recorded in treatment $\mathrm{T}_{10}$ (20:30:40 g NPK $/ \mathrm{m}^{2}$ ) followed by $\mathrm{T}_{9}$ $\left(19: 28.5: 38\right.$ g $\left.\mathrm{NPK} / \mathrm{m}^{2}, 105.73\right)$ while minimum flower yield (65.27) was obtained in treatment $\left(\mathrm{T}_{0}\right)$ control. Significantly maximum flower yield per treatment was due to the chemical fertilizers which provide sufficient nutrition to support vegetative growth and flower formation. There is always a dramatic change in quantity of plant growth when appropriate fertilizers are added. Nitrogen is needed for vegetative growth and is a part of proteins, enzymes, vitamins and chlorophyll and low nitrogen and high potassium level promotes flowering resulting in maximum flower yield. Similar result was obtained by Barad et al., (2010) (Fig. 1).

\section{Economics}

The economic feasibility of each treatment regarding the gross income, total cost of cultivation, net income and benefit cost ratio have been worked out. On perusal of the data presented in the table, it may be seen that maximum yield $\left(40324 / 200 \mathrm{~m}^{2}\right)$, gross income (Rs.241944), net income (Rs.125944) and benefit cost ratio (2.09) was obtained in T10 $\left(20: 30: 40 \mathrm{~g} \mathrm{NPK} / \mathrm{m}^{2}\right)$. The minimum yield $\left(27000 / 200 \mathrm{~m}^{2}\right)$ was recorded with T0 (control), gross income (Rs.162000.) and net income (Rs.46340).

In conclusion, on the basis of present findings it is observed, in respect of cultivation of gerbera, the application of NPK in the ratio of (17:25.5:34 $\left.\mathrm{g} \mathrm{NPK} / \mathrm{m}^{2}\right)$ in $\mathrm{T}_{7}$ was effective for enhancing plant growth except for number of suckers per plant which were recorded to be the best in treatment $\mathrm{T}_{9}(19: 28.5: 38 \mathrm{~g}$ $\left.\mathrm{NPK} / \mathrm{m}^{2}\right)$. Whereas $\mathrm{T}_{10}\left(20: 30: 40 \mathrm{~g} \mathrm{NPK} / \mathrm{m}^{2}\right)$ 
was best regarding flower quality and yield of gerbera. As the study was under taken only for one season, it needs further confirmation by conducting more trials.

\section{References}

Acharya, M.M. and Dashora, L.K. 2004. Response of graded levels of nitrogen and phosphorus on vegetative growth and flowering in African marigold (Tagetes erecta Linn.). J. Ornamental Horticulture, 7(2): 179-183.

Barad, A.V., B.M. Nandre and N.H. Sonwalkar. 2010. Effect of NPK levels on Gerbera cv. Sangria under net house conditions. Indian J. Horticulture, 67(3): 421-424.

Belorkar, P.V., B.N. Patel, V.J. Golliwar and A.J. Kothare. 1992. Effest of nitrogen in spacing on growth, flowering and yield of African marigold. J. Soils and Crops, 2: 62-64.

Dalal, S.R., Gonge, V.S., Pimple, A.G., Deshmukh, R. Utgikar, S. 2005. Response of phosphorus levels to growth, flowering, yield and flower quality of gerbera under polyhouse. Annals of Plant Physiol., 19(1): 120121.

Haque, I. and A.A. Jakhro. 2001. Soil and Fertilizer potassium. In Soil Sci., National Book Foundation, Islamabad Pakistan. pp. 261-263.

Mohariya, A.D., Dalal, S.R Gonge, V.S. Anuje, A.A. 2004. Effect of phosphorus and potash on flower quality and vase life of gerbera grown under polyhouse conditions. The Orissa J. Horticulture, 32(2): 19-21.

Nayak, D., Mandal, T. and Roychowdhury, N. 2005. Effect of NPK nutrition on growth and flowering of Gerbera jamesonii L. cv. Constance. Orissa J. Horticulture, 33(2): 11-15.

Noorul Amin, Muhammad Sajid, Muhammad Mazhar Qayyum, Syed Tanveer Shah, Fazl-i-Wahid, Ratouba Shaheen Hashmi. 2015. Response of Gerbera (Gerbera jamesonii) to different levels of phosphorus and potassium. Int. J. Biosci., 7(4): 1-11.

\section{How to cite this article:}

Tovika J. Ayemi, Devi Singh and Urfi Fatmi. 2017. Effect of NPK on Plant Growth, Flower Quality and Yield of Gerbera (Gerbera jamesonii L.) cv. Ruby Red under Naturally Ventilated Polyhouse Condition. Int.J.Curr.Microbiol.App.Sci. 6(8): 1049-1056.

doi: https://doi.org/10.20546/ijcmas.2017.608.130 